\title{
Influence of body condition score at calving on the metabolic status and production performance of Murrah buffaloes (Bubalus bubalis) during the transition period
}

\author{
Nelson Carvalho Delfino ${ }^{1}$, Lucas Fialho de Aragão Bulcão ${ }^{1}$, Henry Daniel Ruiz Alba ${ }^{1}$, \\ Mauricio Xavier da Silva Oliveira ${ }^{1}$, Filipe Pinheiro Soares de Queiroz ${ }^{1}$, \\ Gleidson Giordano Pinto de Carvalho ${ }^{1}$, Francisco Palma Rennó ${ }^{2}$, and José Esler de Freitas Júnior ${ }^{1, *}$
}

\footnotetext{
* Corresponding Author: José Esler de Freitas Júnior Tel: +55-71-3283-6719, Fax: +55-71-3823-6718,

E-mail: jose.esler@ufba.br

${ }^{1}$ Department of Animal Sciences, School of Veterinary Medicine and Animal Science, Federal University of Bahia (UFBA), Salvador, BA, 40.170-110, Brazil 2 Department of Animal Nutrition and Production, School of Veterinary Medicine and Animal Science University of São Paulo (USP), Pirassununga, SP 13635-900, Brazil
}

ORCID

Nelson Carvalho Delfino

https://orcid.org/0000-0002-8241-2409 Lucas Fialho de Aragão Bulcão

https://orcid.org/0000-0001-8699-1172

Henry Daniel Ruiz Alba

https://orcid.org/0000-0002-8916-2238

Filipe Pinheiro Soares de Queiroz

https://orcid.org/0000-0001-7428-1931

Gleidson Giordano Pinto de Carvalho

https://orcid.org/0000-0002-4108-6782

Francisco Palma Rennó

https://orcid.org/0000-0002-3275-3483

José Esler de Freitas Júnior

https://orcid.org/0000-0003-1559-0149

Submitted Mar 24, 2017; Revised May 31, 2017 Accepted Jul 11, 2017
Objective: The purpose of this study was to evaluate the influence of body condition score (BCS) at calving on the metabolic status of female Murrah buffaloes in the transition period. Methods: Thirty-seven pregnant buffaloes (multiparous) were selected and monitored during the transition period based on their body condition score and on the estimated calving date. Two groups were formed: i) buffaloes with a BCS $>3.5(n=17)$; this group was classified and named 'high BCS at calving' (HBCS); and ii) buffaloes with a BCS $\leq 3.5(n=20)$; this group was classified and named 'low BCS at calving' (LBCS). All animals were monitored during the last 30 days of pregnancy and the first 70 days post-calving and kept in the same environment and under the same feeding and management conditions. Mean values for BCS at calving were $2.98 \pm 0.9$ (mean \pm standard error of the mean $[S E M])$ and $4.21 \pm 0.9($ mean \pm SEM) for the HBCS and LBCS groups, respectively.

Results: The HBCS group showed higher milk fat content $(\mathrm{p}=0.007)$ and milk fat yield $(\mathrm{p}=0.027)$ and a higher concentration of milk urea nitrogen $(\mathrm{p}=0.001)$ than LBCS buffaloes, which in turn had a lower urine $\mathrm{pH}$ value $(\mathrm{p}=0.033)$ than $\mathrm{HBCS}$ buffaloes in the pre-calving period (7.86 for HBCS vs 7.76 for LBCS). The HBCS animals had a higher concentration of erythrocytes $(\mathrm{p}=0.001)$ and hematocrit $(\mathrm{p}=0.012)$ post-calving and a higher hemoglobin concentration $(\mathrm{p}=0.004)$ pre-calving.

Conclusion: Buffaloes during the transition period exhibited some variations in the oxidative stress related to their metabolic status. After calving, buffaloes with a high BCS at calving and greater lipid mobilization have a more marked alteration in oxidative status, but improved production performance.

Keywords: Body Condition Score; Lactation; Metabolism; Pregnancy; Buffaloes

\section{INTRODUCTION}

The transition period is characterized by a decrease in feed intake and an increase in fetal growth and homeorhetic adaptations [1], including mobilization of body reserves. The difference between the lower nutrient intake and increased energy requirements of females for maintenance, own body and fetal growth, and production of colostrum and milk for the newborn leads to a physiological imbalance called negative energy balance $[2,3]$.

Calorimetry studies on high-producing dairy cows have estimated a negative energy balance of $-22 \mathrm{MJ} / \mathrm{d}$ in the sixth week of lactation, decreasing to $-9 \mathrm{MJ} / \mathrm{d}$ in the twelfth week [4]. To reduce the intensity of the negative energy balance through homeorhetic adaptations, a number of metabolic reactions are initiated, with a consequent mobilization of body re- 
serves (especially fats) and reduction of body weight (BW). The lipolytic activity observed with the reduction of body reserves could contribute to $33 \%$ of milk yield or maintain the production of 120 to $550 \mathrm{~kg}$ of milk in the first weeks of production, in dairy cows [5].

The lipolytic activity is correlated with the formation of ketone bodies, which, when in excess, are negatively correlated with the animal health, causing metabolic disorders (ketosis, hypocalcemia, abomasal displasia, and fatty liver), and a reduction in immune response generated by oxidative stress [2,3].

Oxidative stress is associated with the body condition score (BCS) [6], a method to assess the body condition of the animal that is highly correlated with the mobilization of body reserves. Body condition score has the advantage of being a quick, effective, economic, and non-invasive approach. Despite its subjective nature [7], BCS is very important in the establishment of adequate production-management techniques $[5,8]$.

The objective of this study was thus to evaluate the influence of BCS at calving on the metabolic status of female Murrah buffaloes in the transition period. Our hypothesis is that a higher BCS at calving positively influences the concentrations of metabolites in the post-calving transition period, changing the oxidative status and increasing the production performance of these animals.

\section{MATERIALS AND METHODS}

\section{Ethical aspects and location}

This study was conducted in strict conformity with the recommendations of Brazil's National Council for Animal Experimentation (CONCEA). The undertaken experimental procedures were approved by the Ethics Committee in Animal Use of the School of Veterinary Medicine and Animal Science of the Federal University of Bahia, Bahia State, Brazil (no. 39-2014).

\section{Animals, housing, and feeding}

The experiment was conducted in a commercial dairy herd of Murrah buffaloes (Bubalus bubalis). The average milk yield per lactation (300 days in milk) of the herd was higher than $2,400 \mathrm{~kg}$. Thirty-seven pregnant buffaloes (multiparous) were selected based on their BCS and on the estimated calving date. Two groups of BCS at calving were formed, as follows: i) buffaloes with a BCS >3.5 ( $n=17)$; this group was classified and named 'high BCS at calving' (HBCS); and ii) buffaloes with a BCS $\leq 3.5(n=20)$; this group was classified and named 'low BCS at calving' (LBCS). All animals were monitored during the last 30 days of gestation and the first 70 days post-calving and were kept in the same environment and under the same feeding and management conditions. Mean values for BCS at calving were $2.98 \pm 0.9$ (mean \pm standard error of the mean [SEM]) and 4.21 $\pm 0.9($ mean \pm SEM) for groups LBCS and
HBCS, respectively.

The BCS was statistically different between the groups ( $\mathrm{p}<$ 0.001 ). In the post-calving period, all buffaloes were fed chopped elephant grass (Penissetum purpureum) and a concentrate in the form of total mixed ration immediately after milking. The diet (Table 1) was formulated to meet the requirements of lactating buffaloes producing $6.0 \mathrm{~kg} / \mathrm{d}$ milk with $7.0 \%$ fat and $4.2 \%$ crude protein $(\mathrm{CP})$ according to the recommendations of Paul and Lal [9]. After the morning feeding, all buffaloes post-calving were kept in paddocks with Brachiaria decumbens grass (nutrient composition $[\mathrm{g} / \mathrm{kg}$ dry matter $\{\mathrm{DM}\}$ ]: $216.5 \mathrm{DM}, 110.1 \mathrm{CP}, 727.4$ neutral detergent fiber [NDF], and 142.1 non-fibrous carbohydrates [NFC]). The chemical composition of elephant grass can be viewed in the footnote of Table 1.

\section{Sample collection and chemical analysis}

Feed samples were processed through a Wiley mill with 1-mm sieves (AH Thomas, Philadelphia, PA, USA) and analyzed for the DM (AOAC 950.15), ash (AOAC 942.05), ether extract (EE, AOAC 920.39), CP (N×6.25; AOAC 984.13), and lignin (AOAC 973.18) contents according to the methods described by AOAC [10]. The NDF was analyzed using $\alpha$-amylase without addition of sodium sulfide to the detergent (TE-149 analyzer, Tecnal Equipments for Laboratory Inc., Piracicaba, Brazil). The concentrations of NFC were estimated according to [11], as follows: $\mathrm{NFC}=100-[(\% \mathrm{CP}-\% \mathrm{CP}$ from urea $+\%$ urea $)+$

Table 1. Ingredients proportion and chemical-bromatological composition of concentrate

\begin{tabular}{lc}
\hline Item & Diet \\
\hline Ingredients (\% of DM) & \\
Grass (Penissetum purpureum) ${ }^{1)}$ & 80.0 \\
Ground corn & 11.0 \\
Soybean meal & 3.60 \\
Cottonseed & 3.60 \\
Urea & 0.8 \\
Limestone & 0.4 \\
Mineral ${ }^{2)}$ & 0.6 \\
Chemical composition (\% DM) $^{2}$ & \\
Dry matter & 38.1 \\
Crude protein & 11.4 \\
Neutral detergent fiber & 65.3 \\
Non-fiber carbohydrates & \\
Ether extract & 12.5 \\
\hline
\end{tabular}

$D M$, dry matter; $C P$, crude protein; NDF, neutral detergent fiber; NFC, non-fiber carbohydrates.

1) Nutrient composition (g/kg DM): 250.1 DM, 71.0 CP, 768.2 NDF, and 115.1 NFC.

${ }^{2)} \mathrm{kg}$ of the product contains: $190 \mathrm{~g}$ of $\mathrm{Ca}, 60 \mathrm{~g}$ of $\mathrm{P}, 20 \mathrm{~g}$ of $\mathrm{S}, 20 \mathrm{~g}$ of Mg, $35 \mathrm{~g}$ of $\mathrm{K}, 70 \mathrm{~g}$ of $\mathrm{Na}, 15 \mathrm{mg}$ of $\mathrm{Co}, 700 \mathrm{mg}$ of $\mathrm{Fe}, 10 \mathrm{mg}$ of $\mathrm{Cr}, 700 \mathrm{mg}$ of $\mathrm{Cu}_{1}, 40 \mathrm{mg}$ of I, 1,600 mg of Mn, $19 \mathrm{~g}$ of Se, 2,500 mg of Zn, 200,000 IU of Vit A, 50,000 IU of Vit $D_{3}, 1,500 \mathrm{IU}$ of Vit $E$.

${ }^{3)}$ Estimated according to Hall [33]. 
$\% \mathrm{EE}+\% \mathrm{ash}+\% \mathrm{NDF}]$.

\section{Milk yield and composition}

Buffaloes were milked mechanically daily at $0600 \mathrm{~h}$, and their milk yield was measured by an automatic milk meter (Delaval, Tumba, Sweden). Milk yield was corrected to $4.0 \%$ fat (FCM) according to Di Paolo [12]: Y = 1+0.01155 [(X-40)+(Z-31)], where $\mathrm{Y}$ is the amount $(\mathrm{kg})$ of FCM equivalent to $1 \mathrm{~kg}$ of milk produced and $\mathrm{X}$ and $\mathrm{Z}$ are the grams of fat and protein present in $1 \mathrm{~kg}$ of milk produced, respectively. Milk samples were collected automatically (MM6, DeLaval, Sweden) once weekly $(7,14,21,28,35,42,49,56,63$, and 70 days), according to the milk production of each animal in each milking. Milk samples were analyzed fresh for fat, protein, lactose, milk urea nitrogen (MUN), and somatic cell count following Campanile et al [13].

Body condition score, body weight, and clinical parameters During the study, BCS was evaluated using the body-condition scoring method for Murrah buffaloes according to Anitha et al [7]. A graph was used for the classification of condition on a scale of 1 to 5 using 0.5 -point subunits. Measurements were taken weekly by two trained evaluators pre-calving $(-28$, -21 , and -7 days), on the calving date, and post-calving $(+7$, $+14,+21,+28,+35,+42,+49,+56,+63$, and +70 days $)$. The BW was obtained on the same days and used to determine the changes in body condition score and in body weight (BWC). Rectal temperature and heart rate (beats/min, using a stethoscope) were also measured.

\section{Analysis of metabolic status indices}

Blood samples were drawn weekly pre-calving $(-28,-21$, and -7 days), on the calving date, and post-calving $(+7,+14,+21$, and +28 days). Immediately after collection, samples were centrifuged at $2,000 \times g$ for $15 \mathrm{~min}$ at room temperature to obtain the plasma. Plasma samples were sent to the laboratory and analyzed for complete blood count (erythrocytes, hemoglobin, and hematocrit); mean corpuscular hemoglobin concentration (MCHC), by the cyanmethemoglobin colorimetric technique; mean corpuscular volume (MCV), by the micro-hematocrit method; and leukogram (leukocytes, segmented neutrophils, red blood cells, lymphocytes, and neutrophils), by the MayGrunwald Giemsa method. The serum was transferred to plastic tubes that were identified and stored at $-20^{\circ} \mathrm{C}$ until analyses. Analyses were performed using commercial kits in an automatic biochemistry analyzer (BioSystems, Foster City, CA, USA). Blood samples were harvested to measure the serum glucose (K048, Bioclin, Belo Horizonte, Brazil), total protein (K031, Bioclin, Brazil), albumin (K040, Bioclin, Brazil), total cholesterol (K083, Bioclin, Brazil), urea (K056, Bioclin, Brazil), triglycerides (K117, Bioclin, Brazil), calcium (K051, Bioclin, Brazil), and phosphorus (K068, Bioclin, Brazil).

Urine samples were collected from all animals approxi- mately four hours after the morning feeding, when the buffaloes urinated spontaneously. Urine aliquots of $10 \mathrm{~mL}$ were immediately diluted with $40 \mathrm{~mL} 0.036 \mathrm{~N}$ sulfuric acid and stored at $-20^{\circ} \mathrm{C}$ for later analyses pre-calving $(-28,-21$, and -7 days $)$, at calving (until $24 \mathrm{~h}$ post-calving), and post-calving $(+7,+14$, $+21,+28,+35,+42,+49,+56,+63$, and +70 days $)$. The urine $\mathrm{pH}$ values were determined using a digital $\mathrm{pH}$ meter (MB-10, Marte Científica, MG, Brazil). In these samples, we determined the concentrations of urea (fixed-time kinetic method; K056, Bioclin, Brazil); uric acid (UA; enzymatic colorimetric method - K139, Bioclin, Brasil); calcium (Ca; end point colorimetric method - Arzenazo III - K051, Bioclin, Brazil); and sulfur (S) and chlorine $(\mathrm{Cl}$; mercury thiocyanate colorimetric method - K050, Bioclin, Brazil). Potassium (K) was determined using a MH 9180 ion-selective device (MH LabISE 9180, Belo Horizonte, Brazil).

\section{Statistical analysis}

The data were analyzed by the PROC MIXED procedure of SAS [14], according to the model of repeated measures over time, with normality of residuals and homogeneity of variances checked by the PROC UNIVARIATE procedure. The model was used to estimate the effect of physiological stage (week), BCS group (Group 1: BCS>3.5, or HBCS; Group 2: $\mathrm{BCS} \leq 3.5$, or LBCS), and their interaction on oxidative-status indices:

$$
\mathrm{Y}_{i j k}=\mu+\mathrm{W}_{i}+\mathrm{BCS}_{j}+(\mathrm{W} \times \mathrm{BCS})_{i j}+\mathrm{e}_{i j k}
$$

Where $\mathrm{Y}_{i j k}=$ dependent variable; $\mu=$ overall mean of the population; $\mathrm{W}_{i}=$ mean effect of the physiological stage (weeks) ( $i=$ pre-calving, post-calving) with the physiological stage as a repeated factor; $\mathrm{BCS}_{j}=$ mean effect of BCS group $(\mathrm{j}=1$ and 2 ); and $\mathrm{e}_{i j k}=$ unexplained residual element assumed as independent and normally distributed. For each analyzed variable, the buffaloes from both BCS groups were subjected to three covariance structures: compound symmetry, autoregressive order, and unstructured covariance. The data were analyzed on sampling days relative to the calving date, with day 0 representing the calving date.

\section{RESULTS}

\section{BCS and clinical parameters}

The HBCS group had a higher average BW and BCS than LBCS group in the pre- $(\mathrm{p}=0.001)$ and post-calving $(\mathrm{p}=0.001)$ periods (Table 2$)$. There was an effect of weeks $(p=0.001)$ and an interaction effect between weeks and groups for BW ( $\mathrm{p}=$ $0.001)$ and BCS $(\mathrm{p}=0.001)$ during the pre-calving period (Figure $1 \mathrm{~A}, 1 \mathrm{~B})$. However, there was no difference between the groups for BWC pre- and post-calving. There were week effects $(\mathrm{p}=0.001)$ on BWC pre-calving (Figure 1C). HBCS 
Table 2. Body weight, body condition score and clinical parameters in the prepartum and postpartum periods for the groups of body condition score at calving (mean \pm standard error of the mean)

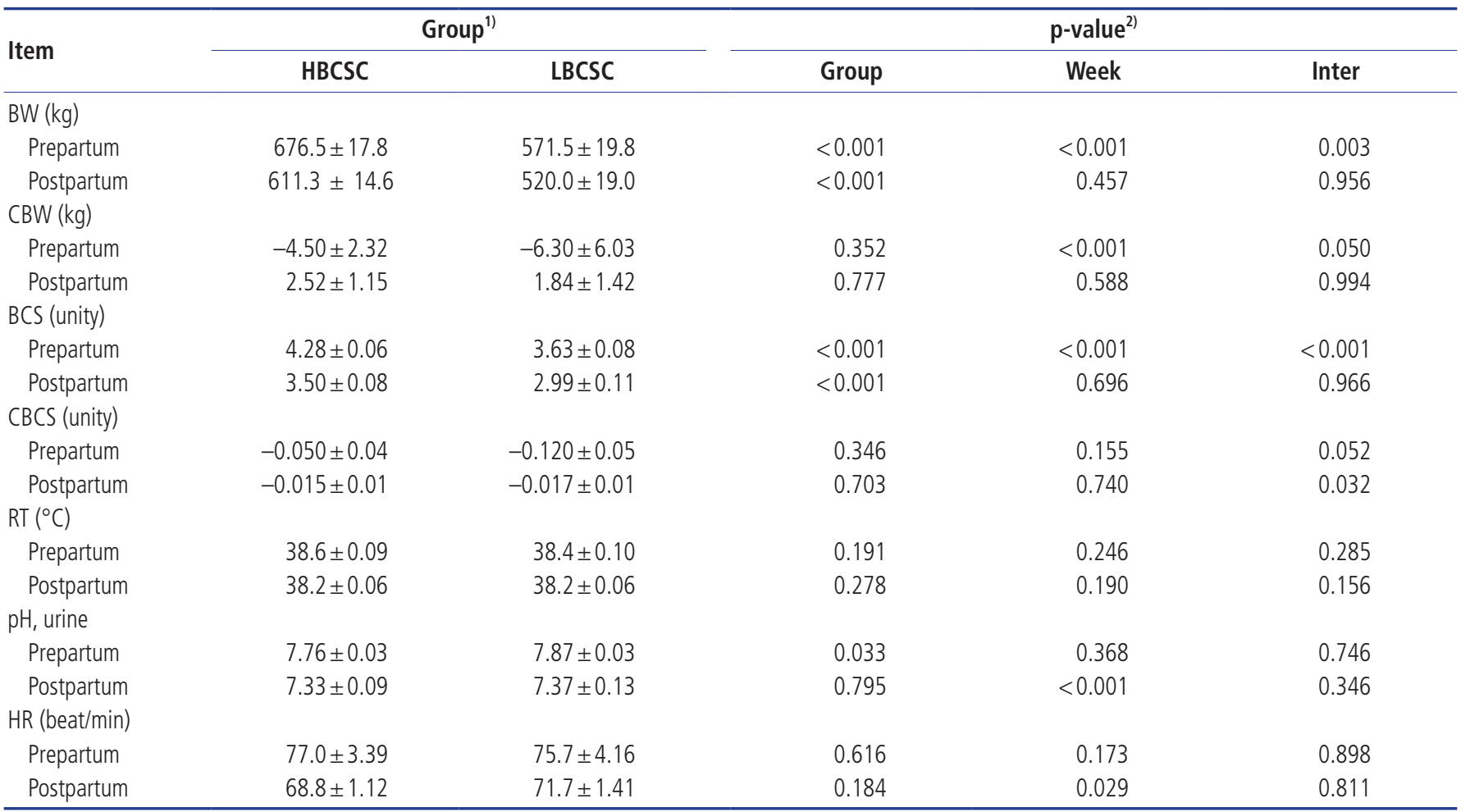

$B W$, body weight; CBW, change in body weight; $B C S$, body condition score; $C B C S$, change in body condition score; RT, rectal temperature; HR, heart rate.

${ }^{1)}$ HBCSC, high body score condition at calving (mean of the group $=4.21$ ); LBCSC, low body condition score at calving (mean of the group $=2.98$ ).

2) Probability values for group, week, and interaction between group $\times$ week (Inter).

A
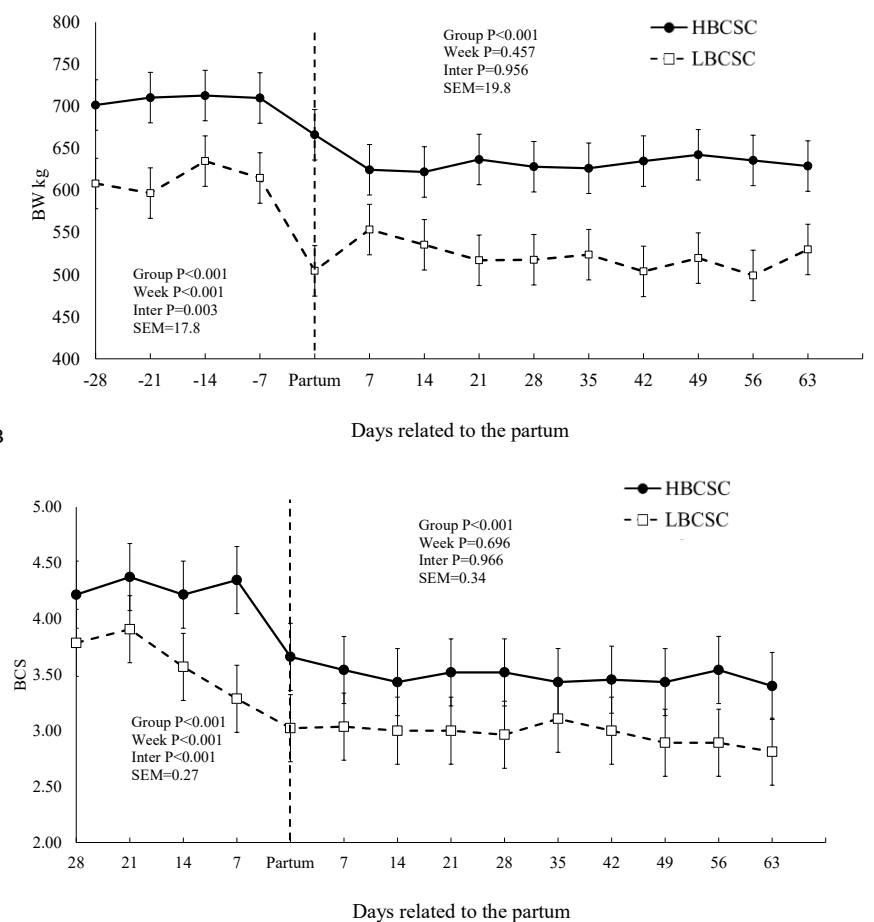

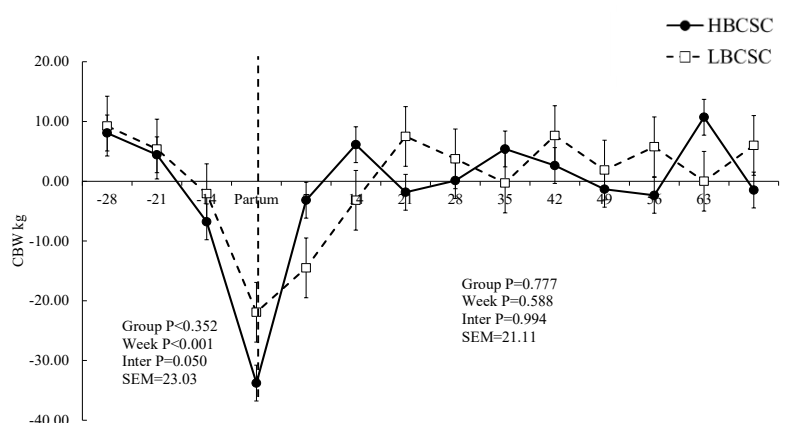

D

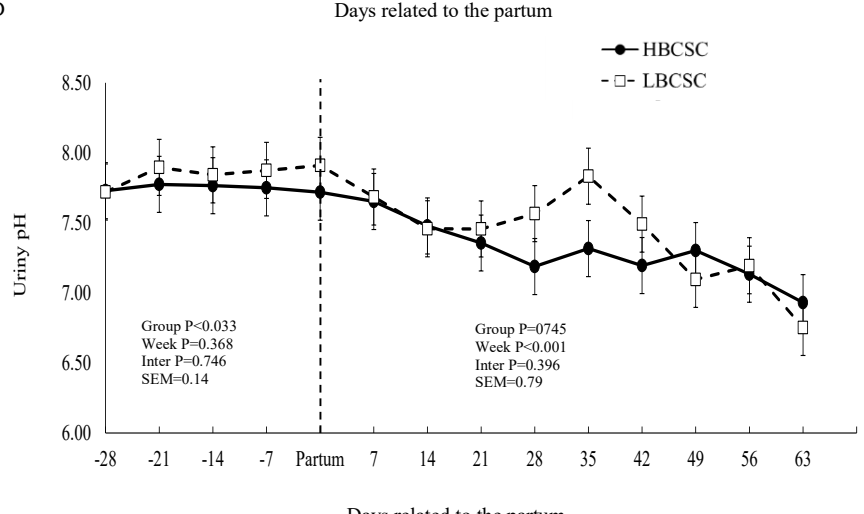

Figure 1. Body weight (BW) (A), body condition score $(B C S)(B)$, change body weight $(C B W)(C)$, and urinary pH values (D), in buffaloes with low body score condition at calving (HBCSC) (Group 1: mean of BCSC $=2.98$ ), and high body score condition at calving (LBCSC) (Group 2: mean of BCSC $=4.21)$. ${ }^{*} p<0.05$, between $L B C S C$ and HBCSC groups. 
buffaloes exhibited higher BCS values than the LBCS group during the pre- $(\mathrm{p}=0.001)$ and post-calving $(\mathrm{p}=0.001)$ periods (Table 2).

The HBCS group showed a higher urine $\mathrm{pH}$ value $(\mathrm{p}=$ 0.033 ) than the LBCS group pre-calving ( 7.76 vs 7.86 , respectively) (Figure 1D, Table 2). There was an effect of weeks ( $\mathrm{p}=$ $0.001)$ for the urine $\mathrm{pH}$ and heart rate values $(\mathrm{p}=0.029)$ during the post-calving period.

\section{Milk yield and composition}

There were no differences for milk yield, FCM, total solids, solids nonfat, protein, and lactose between the groups (Table $3)$. However, the HBCS group had a higher milk fat content $(\mathrm{p}=0.007)$ and milk fat yield $(\mathrm{p}=0.027)$ than the LBCS group (Table 3). There were week effects for the milk protein and lactose concentrations. The HBCS group had a higher MUN content ( $\mathrm{p}=0.001)$ than the LBCS buffaloes ( $28.7 \mathrm{vs} 21.2$, respectively) (Figure 2C, Table 3). There was a week effect in the lactation period for milk casein concentration, casein as a percentage of crude protein, and MUN (Figure 2B).

\section{Metabolic parameters}

There were no differences in the concentrations of erythrocytes, hematocrit, segmented neutrophils, red blood cells, and lymphocytes between the groups in the pre-calving period (Table 4). In the same way, no differences were detected for the concentrations of $\mathrm{MCHC}$, hemoglobin, red blood cells, and lymphocytes between the BCS groups post-calving. However, the HBCS group exhibited higher concentrations of erythrocytes $(\mathrm{p}=0.001)$ and hematocrit $(\mathrm{p}=0.012)$ post-calving and higher levels of $\mathrm{MCHC}(\mathrm{p}=0.002)$ and hemoglobin $(\mathrm{p}=0.004)$ pre-calving (Table 4$)$. The HBCS group showed lower concentrations of MCV ( $\mathrm{p}=0.001)$, leukocytes $(\mathrm{p}=$ $0.001)$, and neutrophils $(\mathrm{p}=0.032)$ pre- and post-calving (MCV $[p=0.001]$, leukocytes $[p=0.016]$, and neutrophils $[p=0.034]$ ). There was a week effect in the post-calving period for the concentrations of erythrocytes, hematocrit, and leukocytes and in the pre-calving period for hemoglobin and leukocytes.

No differences were observed for the concentrations of glucose, urea, triglycerides, and phosphorus between the two groups pre- and post-calving (Table 5). The HBCS group presented higher total plasma protein $(\mathrm{p}=0.035)$, albumin $(\mathrm{p}=$ $0.036)$, and globulin $(\mathrm{p}=0.046)$ in the pre-calving period. However, the LBCS group showed a higher total cholesterol $(\mathrm{p}=$ $0.029)$ and calcium $(\mathrm{p}=0.003)$ post-calving. There was an effect of weeks on the concentrations of glucose $(p=0.040)$ in the pre-calving period and for concentrations of urea $(\mathrm{p}=$ $0.004)$ and total cholesterol $(\mathrm{p}=0.005)$ post-calving.

Urinary concentrations of $\mathrm{K}, \mathrm{S}, \mathrm{Ca}$, urea, and uric acid did not differ between the two groups during the pre- and postcalving periods (Table 6). Likewise, there was no difference for the $\mathrm{Cl}$ concentration between the groups pre-calving. How-

Table 3. Milk yield and composition in buffaloes according to groups of body condition score at calving (mean \pm standard error of the mean)

\begin{tabular}{|c|c|c|c|c|c|}
\hline \multirow{2}{*}{ Item } & \multicolumn{2}{|c|}{ Group ${ }^{1)}$} & \multicolumn{3}{|c|}{ p-value ${ }^{2)}$} \\
\hline & HBCSC & LBCSC & Group & Week & Inter \\
\hline \multicolumn{6}{|l|}{ Production (kg/d) } \\
\hline $\operatorname{FCM}(4.0 \%)^{3)}$ & $11.62 \pm 0.66$ & $9.84 \pm 0.55$ & 0.051 & 0.165 & 0.287 \\
\hline Fat & $0.500 \pm 0.02$ & $0.423 \pm 0.03$ & 0.027 & 0.310 & 0.327 \\
\hline Protein & $0.371 \pm 0.01$ & $0.317 \pm 0.01$ & 0.100 & 0.737 & 0.314 \\
\hline TDE & $1.23 \pm 0.08$ & $1.05 \pm 0.08$ & 0.173 & 0.466 & 0.928 \\
\hline NFDE & $0.852 \pm 0.06$ & $0.728 \pm 0.06$ & 0.296 & 0.569 & 0.980 \\
\hline \multicolumn{6}{|l|}{ Composition (g/100 g) } \\
\hline Fat & $6.43 \pm 0.22$ & $5.70 \pm 0.28$ & 0.007 & 0.755 & 0.095 \\
\hline Protein & $4.80 \pm 0.14$ & $4.85 \pm 0.16$ & 0.899 & $<0.001$ & 0.504 \\
\hline Lactose & $4.71 \pm 0.07$ & $4.79 \pm 0.09$ & 0.374 & $<0.001$ & 0.473 \\
\hline Casein (\% da CP) & $80.93 \pm 0.38$ & $80.42 \pm 0.44$ & 0.374 & $<0.001$ & 0.367 \\
\hline MUN (mg/dL) & $28.7 \pm 1.68$ & $21.2 \pm 1.97$ & $<0.001$ & $<0.001$ & 0.899 \\
\hline SCC (unit/mL) & $344.7 \pm 105$ & $347.3 \pm 135$ & 0.941 & 0.536 & 0.900 \\
\hline
\end{tabular}

FCM, fat-corrected milk; TDE, total dry extract; NFDE, non-fat dry extract; CP, crude protein; MUN, milk urea nitrogen; SCC, somatic cell count.

1) HBCSC, high body score condition at calving (mean of the group = 4.21); LBCSC, low body condition score at calving (mean of the group $=2.98$ ).

2) Probability values for group, week, and interaction between group $\times$ week (Inter).

${ }^{3)}$ Fat-corrected milk $=((($ fat -40$)+($ protein -31$)) \times 0.01155+1) \times$ prod; where "Fat" is the fat content $(\mathrm{g} / \mathrm{kg})$, "Protein" is the protein content $(\mathrm{g} / \mathrm{kg})$ and "Prod" is milk production (kg). 


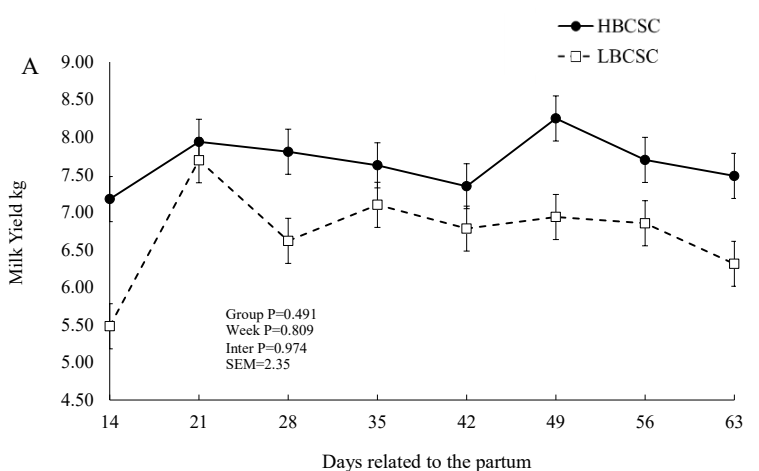

B

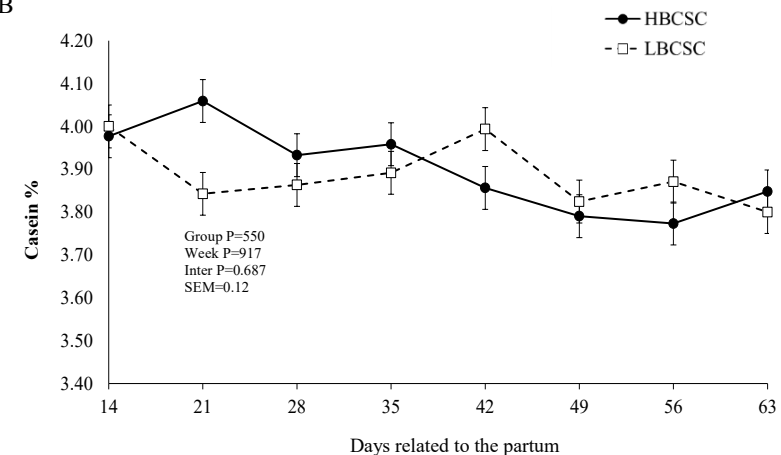

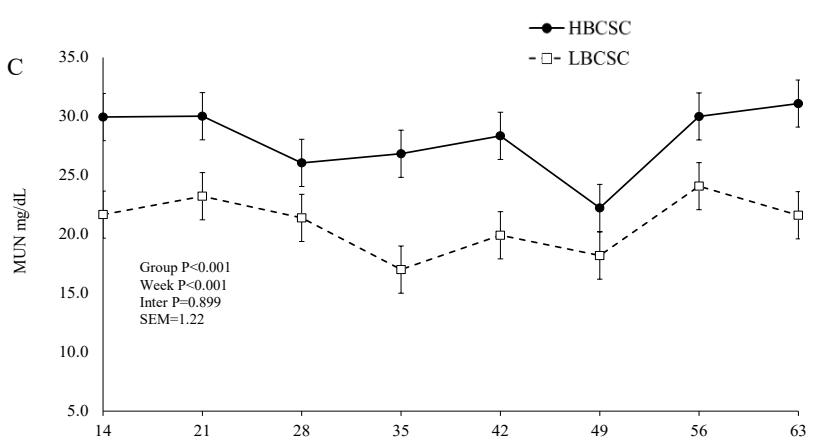

$\mathrm{D}$

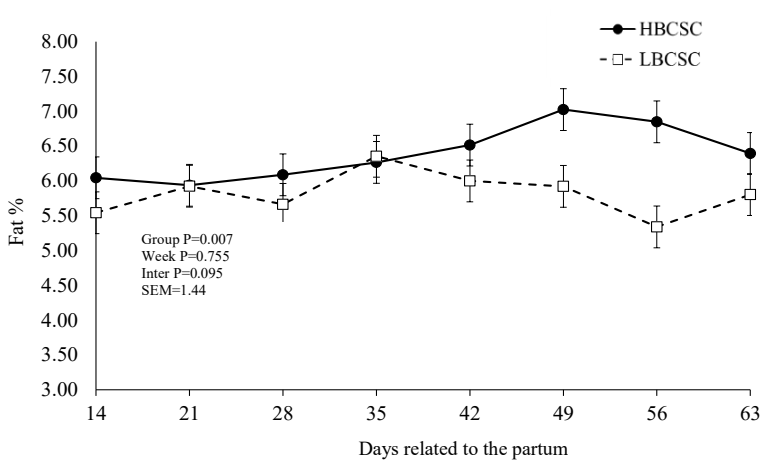

Figure 2. Milk yield (A), casein content (B), milk urea nitrogen (MUN) (C), and milk fat content (D), in buffaloes with low body score condition at calving (HBCSC) (Group 1: mean of BCSC $=2.98$ ), and high body score condition at calving $(\mathrm{LBCSC})$ (Group 2: mean of BCSC $=4.21)$. ${ }^{*} p<0.05$, between $\mathrm{LBCSC}$ and HBCSC groups.

ever, the LBCS group showed a higher $\mathrm{Cl}$ content $(\mathrm{p}=0.010)$ pre-calving. There was a week effect for the concentrations of urea pre- $(\mathrm{p}=0.007)$ and post-calving $(\mathrm{p}=0.014)$. There was an interaction effect between weeks and BCS groups for the $\mathrm{K}$ concentration $(\mathrm{p}=0.030)$ post-calving.

\section{DISCUSSION}

It is known that transition dairy cows with a high BCS lose more BW and body condition than leaner cows $[15,16]$. Over time, buffalo rearing has shifted from a backyard activity to commercial farms and big companies. The immense popularity of buffalo milk and meat-based products has allowed buffalo production to follow the dairy cattle industry. However, in order for this species to perform optimally under the pressure of intensive production systems, buffalo breeds must be improved and research should be conducted with a clear focus on the transition between different physiological stages and alternations in the lipid metabolism $[13,17]$. The BCS at calving explains the concept of homeorhesis, which was defined decades ago as a set of metabolic alterations in the animal that has a genetic key to safeguard important biological functions such as the survival of the newborn (through milk provision) or reproduction [18].

During the pre- and post-calving periods, the HBCS group had higher BW and BCS than the LBCS buffaloes. These re- sults are related to the method adopted and the correlation between BW and BCS $[7,16]$. We observed that the BW loss and the BCS change ( $65.2 \mathrm{~kg}$ and 0.78 points for HBCS vs 51.5 $\mathrm{kg}$ and 0.64 points for LBCS) of the groups during the transition found between the pregnant non-lactating and lactating non-pregnant physiological stages (Figure 1C) was mainly due to the increase in BCS before delivery.

The animals from the HBCS group lost 9.6\% of their initial BW, while the LBCS animals lost $9.0 \%$ of their weight (Table 2 ) in the pre-calving period. The recommended BCS at calving for dairy cows may be different for dairy buffaloes due to differences in metabolism between the species. The endocrine profiles change [17] and the lipolysis and lipogenesis are regulated to increase the lipid reserves during pregnancy; moreover, the lipid metabolism is regulated by homeostatic and homeorhetic mechanisms [18]. Lacetera et al [19] concluded that, after calving, cows that showed an elevated BCS at calving and high lipid mobilization displayed a more pronounced alteration in oxidative status. These conditions may make the cows more sensitive to oxidative stress. In female beef cattle, blood somatropin concentrations are lower and the insulin concentration is higher when compared with dairy-purpose breeds. Breeds have shown decreased milk production according to their dry matter intake [20]. In this study, we have shown that BW and BCS were lower for the LBCS group, indicating that bubaline females present a similar physiological and metabolic 
Table 4. Weekly means values of hemogram for the different groups of body condition score at calving (mean \pm standard error of the mean)

\begin{tabular}{|c|c|c|c|c|c|}
\hline \multirow{2}{*}{ Item } & \multicolumn{2}{|c|}{ Group $^{1)}$} & \multicolumn{3}{|c|}{$p$-value ${ }^{2)}$} \\
\hline & HBCSC & LBCSC & Group & Week & Inter \\
\hline \multicolumn{6}{|l|}{ Erythrocytes } \\
\hline Postpartum & $6.47 \pm 1.12$ & $5.86 \pm 0.47$ & $<0.001$ & 0.001 & 0.630 \\
\hline \multicolumn{6}{|l|}{ Hematocrit } \\
\hline Prepartum & $34.9 \pm 1.05$ & $34.3 \pm 0.93$ & 0.277 & 0.393 & 0.958 \\
\hline \multicolumn{6}{|l|}{$\mathrm{MCHC}$} \\
\hline Prepartum & $34.8 \pm 0.62$ & $33.8 \pm 0.36$ & 0.002 & 0.323 & 0.894 \\
\hline Postpartum & $32.3 \pm 0.96$ & $34.7 \pm 1.26$ & 0.053 & 0.947 & 0.893 \\
\hline \multicolumn{6}{|l|}{ Hemoglobin } \\
\hline Prepartum & $6.47 \pm 0.33$ & $5.86 \pm 0.34$ & 0.004 & 0.001 & 0.636 \\
\hline \multicolumn{6}{|l|}{ Leukocyte } \\
\hline Prepartum & $9,181.8 \pm 1,179$ & $11,167.4 \pm 705$ & 0.001 & 0.029 & 0.192 \\
\hline Postpartum & $10,562.7 \pm 841$ & $11,152.1 \pm 1,084$ & 0.016 & 0.036 & 0.319 \\
\hline \multicolumn{6}{|c|}{ Segmented neutrophil } \\
\hline Prepartum & $4,703.9 \pm 763$ & $4,834.2 \pm 396$ & 0.336 & 0.977 & 0.939 \\
\hline Postpartum & $5,008.9 \pm 570$ & $5,466.4 \pm 732$ & 0.034 & 0.287 & 0.259 \\
\hline \multicolumn{6}{|l|}{ Red blood cell } \\
\hline Prepartum & $3.85 \pm 0.50$ & $4.24 \pm 0.57$ & 0.562 & 0.789 & 0.767 \\
\hline Postpartum & $8.34 \pm 1.12$ & $6.67 \pm 0.47$ & 0.535 & 0.536 & 0.113 \\
\hline \multicolumn{6}{|c|}{ Lymphocytes (\%) } \\
\hline
\end{tabular}

MCHC, mean corpuscular hemoglobin concentration; MCV, mean corpuscular volume.

1) $\mathrm{HBCSC}$, high body score condition at calving (mean of the group $=4.21$ ); LBCSC, low body condition score at calving (mean of the group $=2.98$ ).

2) Probability values for group, week, and interaction between group $\times$ week (Inter).

pattern to that of female beef cattle.

We measured some clinical parameters regarding oxidative stress during the change in physiological stage and there was no difference in RT between the groups. Rectal temperature is an important measurement in the physiological assessment; it is correlated with oxidative stress and albumin production [21]. Celi et al [22] evaluated oxidative stress in dairy cows in the transition period and observed lower plasma albumin concentrations near calving in comparison with a higher concentration at 21 days post-calving, indicating that the cows were under oxidative stress.

The HBCS group had a higher urine $\mathrm{pH}$ value than the LBCS group pre-calving. Alterations in urinary $\mathrm{pH}$ were associated with increased urinary production of $\mathrm{Ca}$, and the metabolic acidosis could have increased the Ca reabsorption of bones and intestines; the $\mathrm{Ca}$ absorption has been attributed an increase in the synthesis of 1,25 (OH) 2 D3 [18]. Never- theless, we did not observe differences in Ca excretion in the urine between the BCS groups (Table 6).

Milk yield was expected to change with the evaluated BCS. However, no differences were detected in milk yield between both BCS groups, although the HBCS group produced $0.75 \mathrm{~kg}$ more. Experiments with dairy cows $[5,8,23]$ have shown that animals with a high BCS at calving had a higher milk fat content. This result may be related to the greater mobilization of body reserves in animals with a higher BCS due to the greater mobilization of body fat (non-esterified fatty acid) from the adipose tissue into the bloodstream [23]. This change can contribute to increasing the group of fatty acids that form the milk fat, thus favoring the capture of long-chain fatty acids from the blood to the mammary gland and resulting in greater incorporation of the milk [23]. Anitha et al [7] evaluated a BCS classification system in Murrah buffaloes in different BCS groups and reported that BCS at calving influenced the milk 
Table 5. Weekly mean values of blood metabolites of different groups of body condition score at calving (mean \pm standard error of the mean)

\begin{tabular}{|c|c|c|c|c|c|}
\hline \multirow{2}{*}{ Item } & \multicolumn{2}{|c|}{ Group ${ }^{1)}$} & \multicolumn{3}{|c|}{$p$-value ${ }^{2)}$} \\
\hline & HBCSC & LBCSC & Group & Week & Inter \\
\hline \multicolumn{6}{|c|}{ Glucose (mg/dL) } \\
\hline Prepartum & $65.4 \pm 3.77$ & $73.1 \pm 2.79$ & 0.087 & 0.275 & 0.659 \\
\hline Postpartum & $74.3 \pm 2.61$ & $73.6 \pm 3.22$ & 0.183 & 0.040 & 0.336 \\
\hline \multicolumn{6}{|c|}{ Total protein (mg/dL) } \\
\hline Prepartum & $8.42 \pm 0.27$ & $7.35 \pm 0.19$ & 0.035 & 0.351 & 0.517 \\
\hline Postpartum & $8.51 \pm 0.21$ & $8.13 \pm 0.27$ & 0.366 & 0.552 & 0.854 \\
\hline \multicolumn{6}{|c|}{ Albumin (mg/dL) } \\
\hline Prepartum & $3.02 \pm 0.10$ & $2.88 \pm 0.07$ & 0.036 & 0.297 & 0.225 \\
\hline Postpartum & $3.07 \pm 0.05$ & $2.99 \pm 0.06$ & 0.111 & 0.298 & 0.473 \\
\hline \multicolumn{6}{|c|}{ Globulin (mg/dL) } \\
\hline Prepartum & $5.33 \pm 0.23$ & $4.51 \pm 0.17$ & 0.046 & 0.303 & 0.525 \\
\hline Postpartum & $5.41 \pm 0.19$ & $4.98 \pm 0.24$ & 0.315 & 0.415 & 0.715 \\
\hline \multicolumn{6}{|l|}{ Urea (mg/dL) } \\
\hline Prepartum & $19.5 \pm 2.58$ & $23.6 \pm 1.74$ & 0.327 & 0.635 & 0.804 \\
\hline Postpartum & $44.3 \pm 3.77$ & $38.5 \pm 4.64$ & 0.022 & 0.005 & 0.278 \\
\hline \multicolumn{6}{|c|}{ Total cholesterol (mg/dL) } \\
\hline Prepartum & $20.3 \pm 1.09$ & $21.0 \pm 0.68$ & 0.156 & 0.601 & 0.417 \\
\hline Postpartum & $26.8 \pm 3.01$ & $34.5 \pm 3.69$ & 0.029 & 0.004 & 0.280 \\
\hline \multicolumn{6}{|c|}{ Triglycerides (mg/dL) } \\
\hline Prepartum & $32.7 \pm 7.45$ & $35.5 \pm 4.91$ & 0.245 & 0.126 & 0.989 \\
\hline Postpartum & $41.0 \pm 3.43$ & $41.7 \pm 4.23$ & 0.618 & 0.997 & 0.320 \\
\hline \multicolumn{6}{|c|}{ Calcium (mg/dL) } \\
\hline Prepartum & $10.3 \pm 0.77$ & $10.2 \pm 0.50$ & 0.684 & 0.172 & 0.718 \\
\hline Postpartum & $7.23 \pm 0.62$ & $9.76 \pm 0.76$ & 0.003 & 0.532 & 0.793 \\
\hline \multicolumn{6}{|c|}{ Phosphorus (mg/dL) } \\
\hline Prepartum & $8.27 \pm 1.17$ & $8.25 \pm 0.77$ & 0.427 & 0.131 & 0.267 \\
\hline Postpartum & $7.93 \pm 0.30$ & $7.74 \pm 0.37$ & 0.125 & 0.250 & 0.290 \\
\hline
\end{tabular}

${ }^{1)} \mathrm{HBCSC}$, high body score condition at calving (mean of the group = 4.21); LBCSC, low body condition score at calving (mean of the group = 2.98).

2) Probability values for group, week, and interaction between group $\times$ week (Inter).

Table 6. Urine metabolites concentrations during the prepartum and postpartum periods (mean \pm standard error of the mean)

\begin{tabular}{|c|c|c|c|c|c|}
\hline \multirow{2}{*}{ Item } & \multicolumn{2}{|c|}{ Group 1$)$} & \multicolumn{3}{|c|}{$p$-value ${ }^{2)}$} \\
\hline & HBCSC & LBCSC & Group & Week & Inter \\
\hline \multicolumn{6}{|l|}{$\mathrm{K}(\mathrm{mg} / \mathrm{dL})$} \\
\hline Prepartum & $159.5 \pm 23.4$ & $150.3 \pm 25.8$ & 0.940 & 0.880 & 0.840 \\
\hline Postpartum & $135.0 \pm 22.3$ & $150.2 \pm 24.9$ & 0.090 & 0.190 & 0.030 \\
\hline \multicolumn{6}{|l|}{$\mathrm{Cl}(\mathrm{mg} / \mathrm{dL})$} \\
\hline Prepartum & $89.7 \pm 10.2$ & $96.8 \pm 10.1$ & 0.490 & 0.100 & 0.350 \\
\hline Postpartum & $58.7 \pm 6.88$ & $83.8 \pm 8.73$ & $<0.001$ & 0.150 & 0.510 \\
\hline \multicolumn{6}{|l|}{$S(\mathrm{mg} / \mathrm{dL})$} \\
\hline Prepartum & $8.56 \pm 2.10$ & $10.18 \pm 2.14$ & 0.630 & 0.350 & 0.980 \\
\hline Postpartum & $12.3 \pm 2.50$ & $12.7 \pm 2.78$ & 0.890 & 0.280 & 0.590 \\
\hline \multicolumn{6}{|l|}{$\mathrm{Ca}(\mathrm{mg} / \mathrm{dL})$} \\
\hline Prepartum & $7.47 \pm 1.15$ & $6.03 \pm 1.13$ & 0.360 & 0.280 & 0.130 \\
\hline Postpartum & $12.44 \pm 1.40$ & $13.44 \pm 1.72$ & 0.840 & 0.630 & 0.790 \\
\hline \multicolumn{6}{|l|}{ Urea (mg/dL) } \\
\hline Prepartum & $176.4 \pm 33.7$ & $260.8 \pm 34.2$ & 0.170 & 0.007 & 0.050 \\
\hline Postpartum & $1,162.4 \pm 112$ & $1,204.4 \pm 141$ & 0.941 & 0.014 & 0.714 \\
\hline \multicolumn{6}{|c|}{ Uric acid (mg/dl) } \\
\hline Prepartum & $3.85 \pm 0.50$ & $4.22 \pm 0.57$ & 0.562 & 0.787 & 0.767 \\
\hline Postpartum & $12.3 \pm 2.50$ & $12.7 \pm 2.78$ & 0.899 & 0.286 & 0.592 \\
\hline
\end{tabular}

1) HBCSC, high body score condition at calving (mean of the group = 4.21); LBCSC, low body condition score at calving (mean of the group $=2.98$ ).

2) Probability values for group, week, and interaction between group $\times$ week (Inter). 
composition (group 1: 2.5 to 2.99; group 2: 3.0 to 3.49; group 3: 3.5 to 3.99 ; and group $4: 4.0$ to 4.49 , which had milk fat contents of $5.82 \%, 6.80 \%, 7.76 \%$, and $8.46 \%$, respectively). Mushtaq et al [24] evaluated a system for the classification of BCS in Nili-Ravi buffaloes and the group with an average BCS of 3.0 presented a milk fat content of $4.56 \%$.

The HBCS group showed a higher MUN content $(\mathrm{p}=0.001)$ than LBCS did. Several factors can change the MUN content, especially nutrition, with an increase in protein intake or an increase in ruminal-degraded protein [25]. The body protein from catabolism and the deamination of the excess dietary protein can contribute to the pool of blood urea nitrogen. As the blood is secreted from the mammary gland, urea is diffused into and out of the gland, coming into balance with the blood urea. This process allows MUN to be an excellent predictor of the blood urea and urinary $\mathrm{N}$ [26]. The HBCS group showed higher concentrations of erythrocytes and hematocrit post-calving and greater concentrations of $\mathrm{MCHC}$ and hemoglobin pre-calving (Table 4). Physiologically, at the end of pregnancy, the number of red blood cells increases as a result of the erythropoietic effect of the chorionic placental somatotropin, progesterone, and prolactin [18]. The erythropoietic effect is the formation of red blood cells, white blood cells (lymphocytes, monocytes, eosinophils, granulocytes, neutrophils, and basophils) and platelets. Similarly, the increased blood volume is a response to the placental uterine circulation and to fetal development, maintaining the tissue oxygenation and blood pressure at adequate levels. However, the nutritional condition can alter the blood volume, the erythropoietic effect, and milk yield. High-producing animals exhibit lower concentrations of blood erythrocytes [27].

The HBCS group showed lower concentrations of leukocytes during the pre- and post-calving periods and a lower level of segmented neutrophils post-calving. Leukocytes participate in the protection of the host against the pathogen and in the monitoring and removal of non-self antigens. The increased blood leukocyte concentrations can be attributed to the lower nutritional condition of the LBCS group at calving. This occurs because an efficient immune response is based on the interaction and on the balance between different types of cells and their products. As the calving date approaches, the total number of leukocytes increases, mainly as a result of the absolute increase in number of neutrophils [28].

High neutrophil levels were shown by LBCS group pre- ( $p$ $=0.032)$ and post-calving $(\mathrm{p}=0.034)$. The decline in nutritional status and increase in oxidative stress can increase the neutrophil concentration, which is explained by the fact that the phagocytosis of the microorganisms is the main function of neutrophils [28]. This represents one of the main lines of defense of the host against pathogens; leukocytes, mainly, are often produced on a large scale in hosts with bacterial load.

The concentrations of urinary metabolites were similar between both groups in the present experiment, except for $\mathrm{Cl}$ (mg/dL), which differed between the groups post-calving. The $\mathrm{K}$ and $\mathrm{Cl}$ concentrations are necessary to maintain the osmotic pressure and acid-base regulation [29]. In the peripartum, there is a positive correlation between the concentrations of calcium, phosphorus, and albumin in the blood [30]. The low concentrations of calcium and phosphorus in the blood observed in the negative energy balance are possibly necessary to sustain milk production [31]. Fiore et al [32] found differences in the blood concentrations of $\mathrm{K}, \mathrm{Cl}$, and $\mathrm{Ca}$ between the pre- and post-calving periods.

\section{CONCLUSION}

Buffaloes during the transition period showed some variations in oxidative status related to their metabolic status. After calving, the buffaloes that had high BCS and lipid mobilization showed a more pronounced change in their oxidative status, but improved production performance. These conditions can make buffaloes less sensitive to oxidative stress.

\section{CONFLICT OF INTEREST}

We certify that there is no conflict of interest with any financial organization regarding the material discussed in the manuscript.

\section{ACKNOWLEDGMENTS}

The authors thank Mr. Urbano Antônio Souza Filho, the dairy company Bufalissima, for their technical assistance and for allowing the use of their animals.

\section{REFERENCES}

1. Grummer RR, Mashek DG, Hayirli A. Dry matter intake and energy balance in the transition period. Vet Clin North Am Food Anim Pract 2004;20:447-70.

2. Al Ibrahim RM, Kelly AK, O'Grady L, et al. The effect of body condition score at calving and supplementation with Saccharomyces cerevisiae on milk production, metabolic status, and rumen fermentation of dairy cows in early lactation. J Dairy Sci 2010;93:5318-28.

3. Berry DP, Lee JM, Macdonald KA, Roche JR. Body condition score and body weight effects on dystocia and stillbirths and consequent effects on postcalving performance. J Dairy Sci 2007;90:4201-11.

4. Beever DE. The impact of controlled nutrition during the dry period on dairy cow health, fertility and performance. Anim Reprod Sci 2006;96:212-26.

5. Rennó FP, Pereira JC, Santos ADF, et al. Effects of body condition at calving on milk yield and composition, lactation 
curve and body reserve mobilization of Holstein cows. Arq Bras Med Vet Zootec 2006;58:220-33.

6. Celi P, Bush DR. Pregnancy, lambing and survival. In: Cottle D, editor. International sheep and wool handbook. Nottingham University Press; 2010. p. 223-57.

7. Anita A, Bao KS, Suresh J, Moorthy RRS, Reddy YK. A body condition score (BCS) system in murrah buffalos. Buffalo Bull 2011;30:77-99.

8. Freitas Jr JE, Rocha Jr VR, Rennó FP, et al. Effect of body condition score at calving on productive performance of crossbred Holstein-Zebu cows. Rev Bras Zootec 2008;37:116-21.

9. Paul SS, Lal D. Nutrient requirements of buffaloes. Satish Serial Publishing House; 2010.

10. AOAC (Association of Official Analytical Chemists) International. Official Methods of Analysis. 17th edn. Gaithersburg, MD, USA: AOAC International; 2000.

11. Hall MB. Calculation of non-structural carbohydrate content of feeds that contain non-protein nitrogen. Gainesville, FL, USA: University of Florida; 2000. p. A-25 (Bulletin-339).

12.Di Palo R. Buffalo milk production with traditional diet and with the use of fatty acids [Ph D Thesis]. Naples, Italy: University of Naples; 1992.

13.Campanile G, Neglia G, DiPalo R, et al. Relationship of body condition score and blood urea and ammonia to pregnancy in Italian Mediterranean buffaloes. Reprod Nutr 2006;46:57-62.

14.SAS (Statistical Analysis System) Institute Inc. User's guide: statistics, version 9. Cary, NC, USA: SAS Inst Inc; 2004.

15. Roche JR, Berry DP, Kolver ES. Holstein-Friesian strain and feed effects on milk production, body weight, and body condition score profiles in grazing dairy cows. J Dairy Sci 2006; 89:3532-43.

16. Roche JR. Milk production responses to pre- and post-calving dry matter intake in grazing dairy cows. Livest Sci 2007;110: $12-24$.

17. Bauman DE. Regulation of nutrient partitioning during lactation: Homeostasis and homeorhesis revisited. In: Cronje $\mathrm{PB}$, editor. Ruminant physiology: digestion, metabolism, growth and reproduction. Wallingford, UK: CAB International; 2000. p. 311-28.

18. Roche JR, Turner LR, Lee JM, et al. Weather, herbage quality and milk production in pastoral systems. 2. Temporal patterns and intra-relationships in herbage quality and mineral concentration parameters. Anim Prod Sci 2009;49:200-10.

19. Lacetera N, Scalia D, Bernabucci U, et al. Lymphocyte functions in overconditioned cows around parturition. J Dairy
Sci 2005;88:2010-6.

20. Shingu H, Hayashi H, Touno E, et al. Characteristics of developmental changes in the kinetics of glucose and urea in Japanese Black calves: comparison with Holstein calves. J Anim Sci 2007;85:2910-5.

21.Ganaie AH, Shanker G, Bumla NA, Ghasura RS, Mir NA. Biochemical and physiological changes during thermal stress in bovines. J Vet Sci Technol 2013;4:1000126.

22. Celi P, Di Trana A, Quaranta A. Metabolic profile and oxidative status in goats during the peripartum period. Aust J Exp Agric 2008;48: 1004-8.

23. Bell AW. Regulation of organic nutrient metabolism during transition from late pregnancy to early lactation. J Anim Sci 1995;73:2804-19.

24. Mushtaq A, Qureshi MS, Khan S, et al. Body condition score as marker of milk yield and composition in dairy animals. J Anim Plant Sci 2012; 22:169-73.

25.Bach A, Calsamiglia S, Stern MD. Nitrogen metabolism in the rumen. J Dairy Sci 2005;88:9-21.

26. Roy B, Brahma B, Ghosh S, Pankaj PK, Mandal G. Evaluation of milk urea concentration as useful indicator for dairy herd management: a review. Asian J Anim Vet Adv 2011;6:1-19.

27. Brun-Hansen HC, Kampen AH, Lund A. Hematologic values in calves during the first 6 months of life. Vet Clin Pathol 2006; 35:182-7.

28. Graugnard DE, Bionaz M, Trevisi E, et al. Blood immunometabolic indices and polymorphonuclear neutrophil function in peripartum dairy cows are altered by level of dietary energy prepartum. J Dairy Sci 2012;95:1749-58.

29. Lager K, Jordan E. The metabolic profile for the modern transition dairy cow. In: Jordan E, editor. Proceedings of the midsouth ruminant nutrition conference 2012. Grapevine, TX, USA: Texas A and M University; 2012. p. 9-16.

30. Alvarenga EA, Moreira GHFA, Facury Filho EJ, et al. Evaluation of the metabolic profile of Holstein cows during the transition period. Rev Bras Zootec 2015;35:281-90.

31.Sundrum A. Metabolic disorders in the transition period indicate that the dairy cows ability to adapt is overstressed. Animals (Basel) 2015; 5:978-1020.

32. Fiore E, Barberio A, Morgante $\mathrm{M}$, et al. Glucose infusion response to some biochemical parameters in dairy cows during the transition period. Anim Sci Pap Rep 2015;33:129-36.

33. Hall MB. Calculation of non-structural carbohydrate content of feeds that contain non-protein nitrogen. University of Florida; Gainesville, FL, USA: 2000. p. A-25. (Bulletin 339). 